\title{
Skin cancer incidence in rural workers at a reference hospital in western Paraná*
}

\author{
Natalia Miolo${ }^{1}$, Rodrigo Fellipe Rodrigues ${ }^{1}$, Emanuelle Reis da Silva ${ }^{1}$, Polyana Klomfass Piati ${ }^{1}$, Orley \\ Alvaro Campagnolo ${ }^{2}$, Leandra Ferreira Marques ${ }^{2}$
}

DOI: http://dx.doi.org/10.1590/abd1806-4841.20197335

\begin{abstract}
BACKGROUND: Skin cancer is common in Brazil and is related to sun exposure, among other risk factors. There are no data on the incidence of malignant skin neoplasm in rural workers in western Paraná.

Овјестіvе: To analyze the incidence and profile of rural workers who were diagnosed with skin cancer at a reference service in Cascavel, western Paraná, in the last five years (2011-2016).

METHODS: This retrospective cross-sectional study was carried out through a review of the anatomopathological reports of rural workers diagnosed with skin cancer at Cascavel Oncology Center (CEONC), in Cascavel. The following variables were collected: year of diagnosis, age, gender, injury location and histological subtype.

RESULTS: A total of 681 cases of malignant epithelial neoplasia were identified, with a higher frequency in the 61-70 age group. Data analysis showed an increase of about $210 \%$ in the occurrence of skin cancers in the last 5 years. The cephalic region was the most affected, and the most common histological subtype was nodular basal cell carcinoma. There was no association between gender and location.

STUDY LimitATIONS: This is a retrospective study and analysis of a secondary data bank.

CONCLUSION: This study is a regional estimation of the incidence of cutaneous neoplasms and provides evidence of a considerable increase in the number of diagnoses in rural workers from western Paraná, Brazil. Moreover, it is possible to conclude that the sample group studied is at risk of developing skin cancer.
\end{abstract}

Keywords: Epidemiology; Incidence; Skin neoplasms; Workers

\section{INTRODUCTION}

The incidence of skin cancer is increasing exponentially around the world. In Brazil, it corresponds to $30 \%$ of all malignant tumors recorded. ${ }^{1}$ The estimate for the USA is that one in every five Americans will develop skin cancer during their lifetime, with around 5.4 million basal cell carcinomas (BCC) and spinocellular carcinomas (SCC) being diagnosed in 2012 alone. ${ }^{2,3}$ Under the same lens, the estimated number of new cases of non-melanoma skin cancer in Brazil in 2016 was 175,760; the number of new cases of the melanoma subtype was 5,670. ${ }^{1,4}$ These values correspond to an estimated risk of 88 new cases of malignant skin neoplasm for every 100 thousand inhabitants/year, according to a calculation based on population data from IBGE. ${ }^{5}$
Among skin tumors, non-melanoma skin cancer has the highest incidence in the world population, but has a low mortality and a high cure rate when detected early. ${ }^{6}$ Conversely, according to national epidemiological data, melanoma skin cancer is estimated to represent only $3 \%$ of malignant neoplasms, while severely affecting quality of life and often leading to metastases and death. ${ }^{1,7}$

Brazil's South region presents a skin cancer incidence above the national rate, with Paraná having the lowest concentration rate among the southern states. The rates among men in Paraná is 5.39 cases per 100 thousand inhabitants for melanoma cancer, and 107.82 per 100 thousand inhabitants for non-melanoma cancer; the rates among women in Paraná is 5.59 cases per 100 thousand inhabitants

\footnotetext{
Received 03 June 2017.

Accepted 20 May 2018.

* Work performed at the Department of Dermatology, Centro Universitário da Fundação Assis Gurgacz, Cascavel (PR), Brazil.

Financial Support: None.

Conflict of interest: None.

Medical School student, Centro Universitário da Fundação Assis Gurgacz, Cascavel (PR), Brazil.

Department of Dermatology, Centro Universitário da Fundação Assis Gurgacz, Cascavel (PR), Brazil.
}

MAILING AdDREss:

Natalia Miolo

E-mail: nataliamiolo@hotmail.com 
for melanoma, and 83.27 per 100 thousand inhabitants for non-melanoma cancer. ${ }^{8}$ Cutaneous neoplasms are a public health problem, and the challenge of combating these diseases requires knowledge of the disease incidence and their variations in the different regions of the country. ${ }^{9}$

A combination of two factors may explain the elevated incidence: the European ancestry of most of the population, which is predisposed to the occurrence of this neoplasm due phenotypic characteristics such as blue eyes, light hair, and skin of phototypes I and II (according to the Fitzpatrick classification), ${ }^{10}$ and sun exposure through increased incidence of ultraviolet radiation (UV), mainly UV-B and UV-A, due to the reduction of the ozone layer over Brazil's South region. ${ }^{11}$

Intrinsic risk factors for the development of the various types of skin cancer include a genetic component (e.g., the presence of dysplastic nevi or of a large number of nevi), skin type (related to the capacity to either tan or burn), and race/ethnicity (closely associated with melanoma). ${ }^{12}$ Compounding the intrinsic factors is excessive exposure to UV rays, which is included in the classification of the physical risks for the development of skin cancer in certain ethnic groups. ${ }^{13}$ As the main occupational risk factor, it makes outdoor workers more vulnerable to developing skin cancer. ${ }^{14}$

It is worth noting that, among the physical risk factors, UV radiation is the primary cause of non-melanoma carcinomas; furthermore, the pattern of exposure may originate different subtypes. ${ }^{15}$ Long-term sun exposure ensures the predominance of spinocellular carcinoma; conversely, basal cell carcinoma is associated with early exposure during one's life and/or intermittent exposure. ${ }^{16-19}$

The Brazilian literature contains few studies on the epidemiological data involving malignant skin neoplasms in rural workers. The reason for this is unknown, considering that the number of cases have increase exponentially over the years - probably resulting from a combination between early detection, greater sun exposure and longer life expectancy. ${ }^{20}$

In addition to the relationship between skin cancer and sun exposure, another factor that favors the development of oncological pathology in the country is the fact that agriculture is one of the main pillars of the Brazilian economy, employing a considerable amount of the work force in the rural regions. In this context, skin cancer presents serious public health challenges, specifically in the area of occupational health. Most work activities in the agricultural sector are performed outdoors, vulnerable to weather variations and to the harmful effects of the sun's rays - about $90 \%$ of these cancers develop in photo-exposed regions of the body. ${ }^{21}$

In light of the above, this work aims to analyze the incidence of the disease and the profile of the rural-worker patients that were diagnosed with skin cancer at the reference service in the city of Cascavel, in western Paraná, between 2011 and 2016.

\section{METHODS}

This study was conducted according to a cross-sectional design, with a search of the data bank of the Cascavel Oncological Center (CEONC). Included in the study were the anatomopathological reports of rural-worker patients diagnosed with skin cancer and treated at the Cascavel Oncological Center (CEONC), in the city of Cascavel (PR), between 2011 and 2016. The city is located in western Paraná. Information on profession, included in the CEONC data bank of electronic medical charts, was based on the declaration of the patients themselves at the time of registration. All positive reports of different histological types of cancer were excluded.

The information extracted from the reports were transferred to a data registration record, created by the authors, using the following variables: year of diagnosis, age, sex, city of origin, location of lesion, and histological subtype.

Regarding histological type, we used the Brazilian Society of Pathology's proposed classification, dividing into basal cell carcinoma (BCC), spinocellular carcinoma (SCC) and melanoma. The histological subtypes of basal cell carcinoma were divided, based on the same reference, into nodular with or without ulceration, undifferentiated, sclerosing, superficial, adenoid cystic, micronodular, and multicentric. Spinocellular carcinoma was divided into three histological subtypes that varied according to the degree of differentiation, as follows: undifferentiated; associated with Bowen's disease; and verrucous. Finally, we established a standardization of the melanomas according to the Breslow index.

To evaluate the relationship between age and the area affected by cancer, we created three age categories: category 1 , for patients up to 55 years old; category 2, comprising patients from 56 to 65 years of age; and category 3 , for patients older than 66 years.

The collected data were entered into the program Microsoft Excel 2010, and the statistical analysis was performed in PAST 3.15 statistical software. Descriptive epidemiology was used to present characteristics of the population under study, with the variables being presented as values of absolute and relative frequency, respectively. For qualitative variables, the proportion of each cancer type in the different categories (age, sex, and affected area) were compared through Pearson's chi-squared test, and a multinomial logistic regression analysis was performed to control the confounding variables related to affected area. The odds ratio (OR) and respective $95 \%$ confidence interval are given, representing the base category for which the lowest risk of the outcome was expected and the significance of the association between the variable in question and the outcome.

The study was approved by the Research Ethics Committee of the Faculdade Assis Gurgacz, under the registration $\mathrm{n}^{\circ}$ 61143416.3.0000.5219. Implementation of the research was approved, through signing of the information letter, by Director Reno Paulo Kunz.

\section{RESULTS}

Between 2011 and 2016, 346 rural-worker patients from western Paraná were identified as having anatomopathological reports of malignant skin neoplasms, diagnosed at the Cascavel Oncological Center (CEONC). Among the patients, 681 cases of skin cancer were diagnosed-grouped into basal cell carcinoma (BCC), spinocellular carcinoma (SCC) and melanoma-confirming its recurrent nature in the patients analyzed.

Of the 681 cases, 170 (24.96\%) occurred in females. The ages of the patients ranged from 31 to 100 years; the age group with the highest prevalence of epithelial neoplasms was 61-70 years. Graphic 1 shows the patients categorized by age range, according to the 
frequency of cases. To assess the relationship between age and the site affected by cancer, three age categories were created: category 1 , for patients up to 55 years old; category 2, comprising patients from 56 to 65 years of age; and category 3 , for patients older than 66 years.

We found the age factor to be statistically significant only for the following types of cancer: multicentric BCC ( $p=0.02)$, superficial BCC $(p=0.0001)$, undifferentiated SCC $(p=0.002)$ and T1 melanoma $(\mathrm{p}=0.01)$. For the other types of cancer, age was not a risk factor (Graphic 1).

When comparing the individuals by age, the chance of acquiring multicentric BCC is $89 \%$ less for people older than 66 years $(\mathrm{OR}=0.11$ (0.01-0.95). For superficial BCC, the chance of acquisition is estimated to be 7.32 times greater for people between 56 and 65 years $(\mathrm{OR}=7.32$ (2.13-25.1); $\mathrm{p}=0.0001)$; people older than 66 years are $66 \%$ less likely to acquire this type of cancer (OR=0.34 (0.16$0.70) ; \mathrm{p}=0.0001$ ). For undifferentiated SCC, the chance of acquisition is 2.28 times greater for people older than 66 years $(\mathrm{OR}=2.28$ (1.38-3.79); $\mathrm{p}=0.002)$. For T1 melanoma, the risk is $81 \%$ lower for individuals older than 66 years $(\mathrm{OR}=0.19(0.06-0.62) ; \mathrm{p}=0.01)$.

Table 1, which generally analyzes the major types of skin cancer, shows that the incidence of BCC was similar between the sexes. Conversely, SCC had greater involvement among men, while melanoma had a considerably higher incidence among women. In relation to age, both BCC and SCC occurred with greater frequency in patients older than 66 years. In contrast, melanoma presented predominantly in patients up to 55 years of age.
A gender differential in incidence rates was found only for the following types of cancer: multicentric BCC $(p=0.01)$, superficial BCC ( $p=0.002)$, SCC associated with Bowen's disease (0.004), undifferentiated SCC $(p=0.005)$ and TI melanoma $(p=0.0001)$. For the other types of cancer, the sex was not a risk factor, as shown in table 2.

According to the values given in table 2, it can be inferred that, for multicentric BCC, the chance of acquisition is $671 \%$ greater for women than for men. For superficial BCC, the chance of acquisition is estimated to be $187 \%$ greater for women than for men. For SCC associated with Bowen's disease, the chance of acquisition is estimated to be $315 \%$ greater for women than men. For undifferentiated SCC, women are 50\% less likely than men to acquire the

\begin{tabular}{|c|c|c|c|c|c|}
\hline \multirow[b]{2}{*}{$\begin{array}{l}\text { Type of } \\
\text { cancer }\end{array}$} & \multicolumn{2}{|c|}{$\operatorname{Sex}(n \%)$} & \multicolumn{3}{|c|}{ Age } \\
\hline & Female & Male & $\begin{array}{c}\text { Up to } \\
55 \text { years }\end{array}$ & $\begin{array}{l}56-65 \\
\text { years }\end{array}$ & $\begin{array}{c}66 \text { years } \\
\text { and } \\
\text { older }\end{array}$ \\
\hline BCC & $\begin{array}{c}121 \\
(71.1 \%)\end{array}$ & $\begin{array}{c}359 \\
(70.2 \%)\end{array}$ & $\begin{array}{c}132 \\
(72.9 \%)\end{array}$ & $\begin{array}{c}130 \\
(72.2 \%)\end{array}$ & $\begin{array}{c}218 \\
(68 \%)\end{array}$ \\
\hline SCC & $\begin{array}{c}29 \\
(17 \%)\end{array}$ & $\begin{array}{c}130 \\
(25.4 \%)\end{array}$ & $\begin{array}{c}30 \\
(16.5 \%)\end{array}$ & $\begin{array}{c}37 \\
(20.5 \%)\end{array}$ & $\begin{array}{c}92 \\
(28.7 \%)\end{array}$ \\
\hline Melanoma & $\begin{array}{c}20 \\
(11.7 \%)\end{array}$ & $\begin{array}{c}22 \\
(4.3 \%)\end{array}$ & $\begin{array}{c}19 \\
(10.4 \%)\end{array}$ & $\begin{array}{c}13 \\
(7.2 \%)\end{array}$ & $\begin{array}{c}10 \\
(3 \%)\end{array}$ \\
\hline Total & 170 & 511 & 181 & 180 & 320 \\
\hline
\end{tabular}

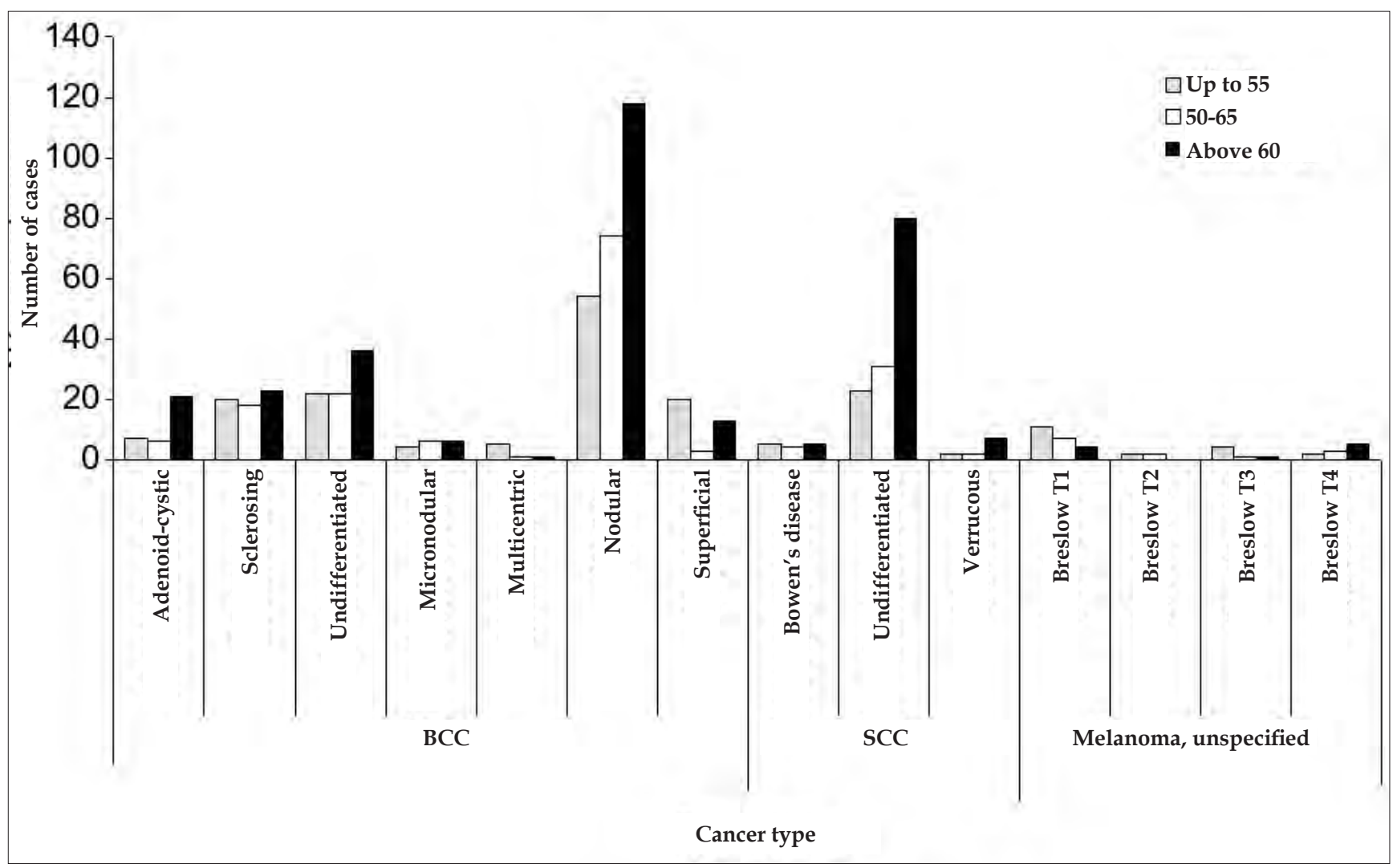

GraPHIC 1: Distribution of the number of skin cancer cases, by subtype, according to age group 
disease; and for T1 melanoma, the risk for females is $464 \%$ greater.

The frequency of carcinomas, per gender, diagnosed relative to their anatomical localization in the patients, is presented in graphic 2 . There was a predominance of BCC in the cephalic region, principally on the middle third of the face.

According to graphic 2, the sex factor had no influence on the site of cancer occurrence, since both genders presented a similar incidence for the occurrence.

The most frequent histological type, according to the classification proposed by the Brazilian Society of Pathology, ${ }^{22}$ was basal cell carcinoma, with 480 cases - corresponding to $70.32 \%$ of the total-followed by spinocellular carcinoma $(23.53 \%)$ and, finally, by melanoma (6.14\%).

The most frequent histological subtype among the basal cell carcinomas, again according to the classification proposed by the Brazilian Society of Pathology, was nodular (51.25\%) with or without ulceration, followed by undifferentiated $(16.67 \%$, sclerosing $(12.70 \%)$, superficial $(7.5 \%)$, adenoid cystic $(7.08 \%)$, micronodular $(3.33 \%)$ and, lastly, multicentric (1.54\%); however, it should be noted that $16.67 \%$ were not classified. ${ }^{22}$

The spinocellular carcinoma histological type was also subdivided, forming three histological subtypes that vary according to the degree of differentiation. They are, from highest to lowest incidence, as follows: undifferentiated (84.27\%); associated with Bowen's disease (8.08\%); and verrucous $(6.91 \%)$.

Using globally recognized classification criteria, the Breslow index confers the most meaningful values in the prediction of disease progression, as it describes the thickness of the melanoma (measured in millimeters) and the presence or absence of ulceration (determined histopathologically) ${ }^{23,24}$ The thinner the melanoma, the greater the chance of curing it. On that basis, a standardization for melanomas was established according to the Breslow index, with the following findings: melanoma Breslow T1 (52.38\%), followed by Breslow T4 (23.80\%), Breslow T3 (14.28\%) and, lastly, melanoma with Breslow T2 subtype (9.52\%).

In relation to the year of diagnosis, 55 cases were reported in 2011; 79 cases in the following year; and 91 cases in 2013. In 2014, there were 118 cases; in 2015, there was an increase of 53 cases, reaching 171 by the end of the year; and in the final year of analysis, 2016, 167 cases were recorded.

\section{DISCUSSION}

We analyzed 681 reports of anatomopathological diagnoses of malignant skin neoplasms in rural-worker patients treated at the Cascavel Oncology Center (CEONC), in the municipality of Cascavel (PR), between 2011 and 2016. Cascavel is a regional pole and a reference center for 52 cities in the west region of Paraná; the sample is, therefore, representative of the study region. The total number of cases diagnosed per year has increased in the number of skin cancers over a five-year period, with 55 cases in the first year of the study (2011) and 167 cases in the last year (2016).

This increase can be explained by the increment in the number of diagnoses made in the municipality, due to the greater knowledge and awareness that doctors and patients have about the lesion; by the intensification of solar radiation; and by rural workers' habit being exposed to the sun without protection..$^{25}$

An additional, associated factor is the increase in ultraviolet radiation resulting from the depletion of the ozone layer. It is predicted that, for every $10 \%$ reduction in the ozone layer, there is an increase of $40 \%$ in the incidence of skin cancer. ${ }^{26}$ Furthermore, a majority of the population of Paraná has light skin, owing to European colonization, and is therefore more susceptible to damage caused by ultraviolet radiation. This point emphasizes the fact that skin cancer, whether melanoma or non-melanoma, is the most common malignancy in Caucasians. ${ }^{27,28}$

TABLE 2: Univariate analysis of skin cancer subtypes relative to gender

\begin{tabular}{|c|c|c|c|c|c|}
\hline \multirow{2}{*}{ Type of cancer } & \multicolumn{2}{|c|}{$\operatorname{Sex}(n \%)$} & \multicolumn{3}{|c|}{ Univariate analysis } \\
\hline & Female & Male & OR (IC95\%) & $\mathbf{X}^{2}$ & $p$ \\
\hline Adenoid cystic BCC & $4(2.3 \%)$ & $30(5.8 \%)$ & $0.38(0.13-1.11)$ & 3.32 & 0.06 \\
\hline Sclerosing BCC & $19(11.1 \%)$ & $42(8.2 \%)$ & $1.40(0.79-2.49)$ & 1.36 & 0.24 \\
\hline Undifferentiated BCC & $18(10.5 \%)$ & $62(12 \%)$ & $0.85(0.49-1.49)$ & 0.29 & 0.58 \\
\hline Micronodular BCC & $3(1.7 \%)$ & $13(2.5 \%)$ & $0.68(0.19-2.44)$ & 0.33 & 0.56 \\
\hline Multicentric BCC & $5(2.9 \%)$ & $2(0.3 \%)$ & $7.71(1.48-40.1)$ & 8.15 & 0.01 \\
\hline Nodular BCC & $55(32 \%)$ & $191(37 \%)$ & $0.8(0.55-1.15)$ & 1.39 & 0.23 \\
\hline Superficial BCC & $17(10 \%)$ & $19(3.7 \%)$ & $2.87(1.49-5.67)$ & 10.05 & 0.002 \\
\hline SCC associated with Bowen's disease & $8(4.7 \%)$ & $6(1.1 \%)$ & $4.15(1.42-12.16)$ & 7.90 & 0.004 \\
\hline Undifferentiated SCC & $21(12.3 \%)$ & $113(22 \%)$ & $0.49(0.30-0.82)$ & 7.68 & 0.005 \\
\hline Verrucous SCC & $0(0 \%)$ & $11(2.1 \%)$ & 0 & 3.71 & 0.06 \\
\hline Melanoma NOS. Breslow T1 & $14(8.2 \%)$ & $8(1.5 \%)$ & $5.64(2.34-13.7)$ & 3.82 & 0.0001 \\
\hline Melanoma NOS. Breslow T2 & $2(1.1 \%)$ & $2(0.39 \%)$ & $3.02(0.42-21.6)$ & 1.34 & 0.24 \\
\hline Melanoma NOS. Breslow T3 & $1(0.5 \%)$ & $5(0.9 \%)$ & $0.59(0.06-5.16)$ & 0.22 & 0.64 \\
\hline Melanoma NOS. Breslow T4 & $3(1.7 \%)$ & $7(1.3 \%)$ & $1.29(0.33-5.05)$ & 0.13 & 0.71 \\
\hline Total & 170 & 511 & & & \\
\hline
\end{tabular}

*NOS - Not otherwise specified 


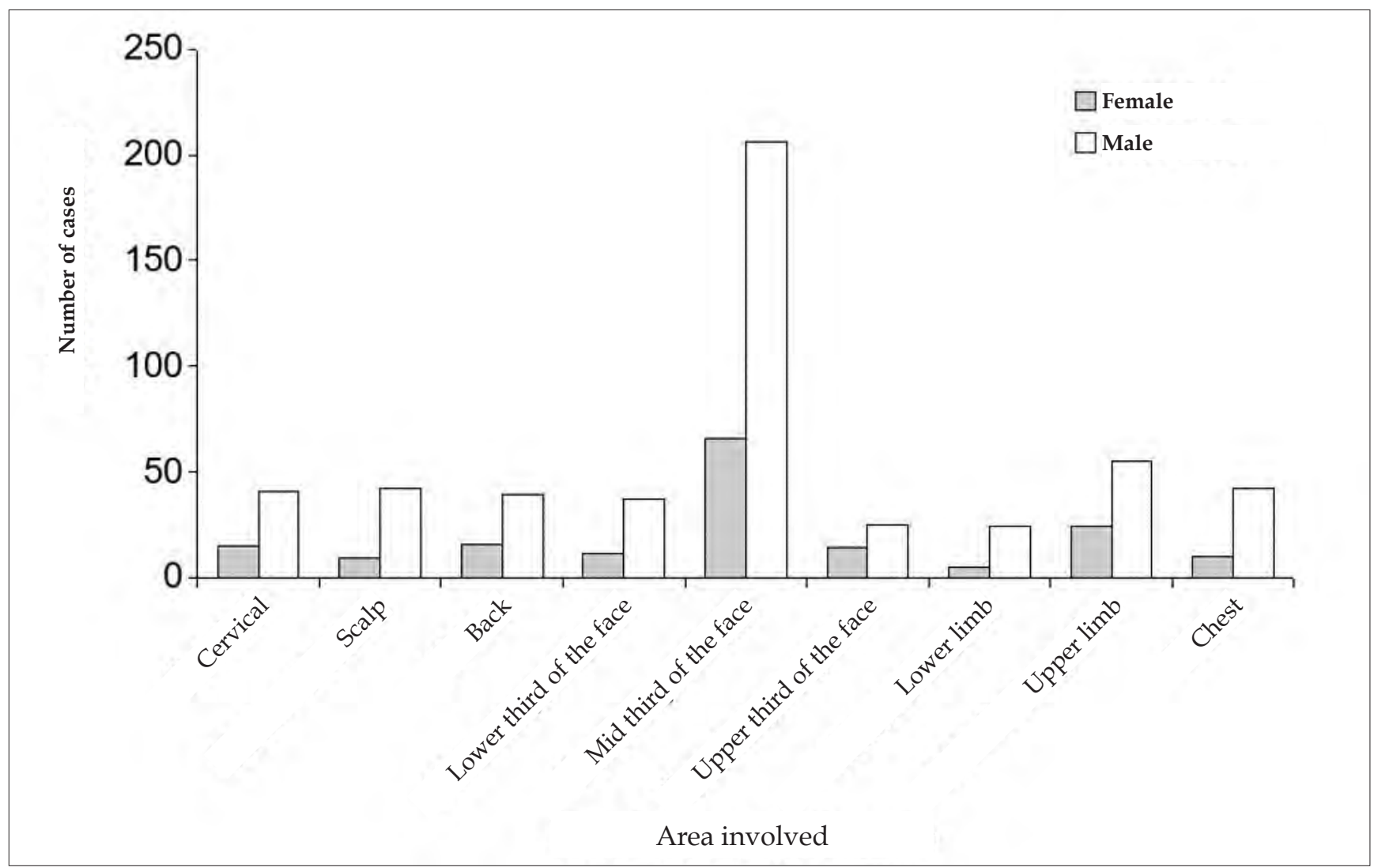

Graphic 2: Distribution of the number of diagnosed cases in relation to anatomical location and gender

Overall, 681 cases were analyzed, with only 170 (24.96\%) of them occurring in women, a finding consistent with similar studies that confirm the lower participation of women in professions that involve a high level of sun exposure. ${ }^{29}$

The gender differential in the incidence of neoplasms was found only for the following types of cancer: multicentric BCC $(p=0.01)$, superficial BCC $(p=0.002)$, SCC associated with Bowen's disease $(p=0.004)$, undifferentiated SCC $(p=0.005)$, and T1 melano$\mathrm{ma}(\mathrm{p}=0.0001)$. However, for the other types of cancer, the sex was not a risk factor. It should be noted that the chance of acquisition among women was greater for multicentric BCC, SCC associated with Bowen's disease, and T1 melanoma.

The general analysis of skin cancer types found that the incidence of BCC was similar between sexes; in contrast, SCC affected a greater number of men, and melanoma had a considerably higher incidence in women. These data refute the studies that evaluate the general population without specifying rural workers, in which the worldwide incidence of basal cell carcinoma and spinocellular carcinoma was, respectively, 1.5 times higher and 1.9 times higher in men than in women. ${ }^{30}$

In rural workers, however, the higher incidence of melanoma in women leads us to infer that their sun exposure is more intermittent and in high doses, a possible conclusion being that they assist during harvest periods. For the non-melanoma type, particularly SCC, the incidence increases with age and is higher in men than women, confirming that cumulative and continuous sun expo- sure favors its development.

Although the analysis showed that skin cancer affected significantly more men than women, across all evaluated age groups, the sex factor had no influence on the cancer's site of occurrence.

In terms of age, the largest proportion of cases were found for the 61-70 age group. However, to evaluate the influence of age on the site affected by cancer, three age categories were created: category 1 , for patients up to 55 years old; category 2, comprising patients from 56 to 65 years of age; and category 3, for patients 66 years and older. In the general analysis of these categories, the one with the highest concentration of cancers was category 3-66 years and older - with 320 cases. This datum may be explained by the fact that rural workers spend more time exposed to risk factors for cancer development, particularly the cumulative effect of intense and intermittent sun exposure. ${ }^{31}$

Most skin carcinomas arise in areas of the body subject to frequent sun exposure. ${ }^{32}$ In this work, $60 \%$ of all cancers were in the cephalic segment, the middle third of the face being the site of the largest proportion (39.9\%) of cancers, corroborating other studies that evaluated the basal cell subtype exclusively. ${ }^{33}$

This finding reinforces the importance of chronic sun exposure as a risk factor - the face being a site frequently exposed to the sun-especially considering that many outdoor workers do not use any type of sunscreen. ${ }^{34,35}$ It is noteworthy that Regulatory Norm (RN) 31 advocates the provision of personal protection equipment (PPE) for rural workers exposed to the sun, such as a wide-brimmed 
hat or a flap cap, non-ionizing radiation protection glasses, and fullbody protection for jobs that carry a risk of heat-related injury. ${ }^{36}$ However, there is no legislation that mandates the use of sunscreen. Its use ought to be indicated for specific areas of the skin for which PPE cannot provide the desired protection.

In terms of histological type, the most frequent was nodular basal cell carcinoma, with or without ulceration (36.12\%), its prevalence being in accordance with the findings of other studies; however, no other studies compared its prevalence with all carcinoma subtypes. ${ }^{32,37}$

The incidence of this type of neoplasm can be explained by an occupational exposure that occurs intermittently, which is important in the development of basal cell carcinoma and melanoma. For SCC, however, continuous exposure is more relevant. Cumulative and excessive exposure during the first 10-20 years of life is considered to increase the risk of skin cancer. ${ }^{38}$

Among the limitations of this study, the foremost is its design, since causality cannot be established in cross-sectional studies, and some variables (skin phototype, frequency of sun exposure, use of physical and chemical protection, among other aspects) were impossible to assess because the data were obtained from a secondary data bank. Furthermore, some of the reports lacked data, compromising the analysis of the results and possibly leading to some information bias.

Regarding the observed data, it should be emphasized that skin cancer is an occupation- and environment-based disease, which requires prevention. Its global epidemiology demonstrates that, compared to indoor workers, outdoor workers are at significant risk of developing skin cancer. ${ }^{39,40}$ From another perspective, more population studies are needed to assess the real magnitude of the problem and its repercussions on public heath, particularly in the group studied.

This study revealed the reality of this neoplasm's behavior in the rural workers treated in Cascavel, western Paraná. Through this study, it was possible to identify a high-risk group and its behavioral elements. This information supports sanitary measures for primary protection among the general population-such as detection campaigns, the promotion of educational programs in schools and communities, and the optimization of public health and workers' health actions, thereby reducing morbidity and healthcare system expenditures through recognition and early treatment of lesions $^{37}$-and it promotes the reduction of skin cancer incidence in future generations.

\section{CONCLUSION}

The study of 681 anatomopathological exam reports of rural workers diagnosed with skin cancer at the Cascavel Oncological Center (CEONC), between 2011 and 2016, leads us to conclude that the incidence of the disease has increased significantly, being most prevalent in men and affecting people older than 65 in particular. The site most affected was the cephalic region, and the most common histological subtype was nodular basal cell carcinoma, followed by undifferentiated squamous cell carcinoma. This study is a regional estimate of the incidence of cutaneous neoplasms and provides evidence of a considerable increase in the number of skin cancer diagnoses in rural-worker patients in Paraná, Brazil. Moreover, it is possible to conclude that the sample group studied seems to be at risk of developing skin cancer. $\square$

\section{REFERENCES}

1. Inca.gov.br [Internet]. Instituto Nacional de Câncer José Alencar Gomes da Silva (INCA). Tipos de câncer: Câncer de Pele melanoma no Brasil. Rio de Janeiro: Inca; 2016. [cited 2017 Jan 7]. Available from: http://www2.inca.gov.br/wps/ wcm/connect/tiposdecancer/site/home/pele melanoma.

2. Noury K. Skin Cancer. Australia: Mc Gralw Hill; 2007.

3. Rogers HW, Weinstock MA, Feldman SR, Coldiron BM. Incidence estimate of nonmelanoma skin cancer (keratinocyte carcinomas) in the US population, 2012. JAMA Dermatol. 2015;151:1081-6.

4. Inca.gov.br [Internet]. Instituto Nacional de Câncer José Alencar Gomes da Silva (INCA). Tipos de câncer: Câncer de Pele não melanoma no Brasil. Rio de Janeiro: Inca; 2016. [cited 2017 Jan 7]. Available from: http://www2.inca.gov.br/wps/ wcm/connect/tiposdecancer/site/home/pele_nao_melanoma.

5. Ibge.gov.br [Internet]. Instituto Brasileiro de Geografia e Estatística (IBGE). Projeção da população do Brasil e das Unidades da Federação. 2016. [cited 2017 Jan 19]. Available from: http://www.ibge.gov.br/apps/populacao/projecao/.

6. Sbd.org.br [Internet]. Sociedade Brasileira de Dermatologia. Câncer da pele. [cited 2016 Dec 2]. Available from: http://www.sbd.org.br/doencas/cancer-da-pele/.

7. Lomas A, Leonardi-Bee J, Bath-Hextall F. A systematic review of worldwide incidence of nonmelanoma skin cancer. Br J Dermatol. 2012:166:1069-80.

8. Inca.gov.br [Internet]. Instituto Nacional de Câncer José Alencar Gomes da Silva (INCA). Estimativas 2016: Incidência de Câncer no Brasil - Paraná e Curitiba. Rio de Janeiro: Inca; 2016. [cited 2017 Jan 10]. Available from: http://www.inca.gov. br/estimativa/2016/parana-curitiba.asp
9. Nasser N. Incidência de câncer de pele na região sul do Brasil. An Bras Dermatol. 1986;61:69-72

10. Custódio G, Locks LH, Coan MF, Gonçalves C0, Trevisol DJ, Trevisol FS. Epidemiology of basal cell carcinomas in Tubarão, Santa Catarina (SC), between 1999 and 2008. An Bras Dermatol. 2010;85:819-26.

11. Sociedade Brasileira de Dermatologia. Data analysis of the Brazilian Society of Dermatology skin cancer prevention campaign, 1999 to 2005. An Bras Dermatol 2006;81:529-35.

12. Surgeongeneral.gov [Internet]. U.S. Department of Health ans Human Services. The Surgeon General's Call to Action to Prevent Skin Cancer. Washington (DC): U.S. Dept of Health and Human Services, Office of the Surgeon General; 2014. [cited 2018 Jan 7].Available from: https://www.surgeongeneral.gov/library/calls/ prevent-skin-cancer/call-to-action-prevent-skin-cancer.pdf.

13. Gruber SB, Armstrong BK. Cutaneous and ocular melanoma. In: Schottenfeld D, Fraumeni Jr. JF, editors. Cancer Epidemiology and Prevention. 3rd ed. New York: Oxford University Press; 2006. p.1196-229.

14. Sena JS, Girão RJ, Carvalho SM, Tavares RM, Fonseca FL, Silva PB, et al. Occupational skin cancer: Systematic review. Rev Assoc Med Bras (1992). 2016;62:280-6.

15. Xiang F, Lucas R, Hales S, Neale R. Incidence of nonmelanoma skin cancer in relation to ambient UV radiation in white populations, 1978-2012: empirical relationships. JAMA Dermatol. 2014;150:1063-71.

16. Strickland PT, Vitasa BC, West SK, Rosenthal FS, Emmett EA, Taylor HR. Quantitative carcinogenesis in man: solar ultraviolet $B$ dose dependence of skin 
cancer in Maryland watermen. J Natl Cancer Inst. 1989;81:1910-3.

17. Kricker A, Armstrong BK, English DR, Heenan PJ. Does intermittent sun exposure cause basal cell carcinoma? a case-control study in Western Australia. Int J Cancer. 1995;60:489-94.

18. Raasch B, Maclennan R, Wronski I, Robertson I. Body site specific incidence of basal and squamous cell carcinoma in an exposed population, Townsville, Australia. Mutat Res. 1998:422:101-6.

19. Franceschi S, Levi F, Randimbison L, La Vecchia C. Site distribution of different types of skin cancer: new aetiological clues. Int J Cancer. 1996;67:24-8.

20. Cancer.org [Internet]. American Cancer Society. Key Statistics for Basal and Squamous Cell Skin Cancers. [cited 2017 Jan 19]. Available from: https://www. cancer.org/cancer/basal-and-squamous-cell-skin-cancer/about/key-statistics.html

21. Brasil. Ministério da Saúde. Organização Pan-Americana da Saúde no Brasil. Doenças relacionadas ao trabalho: manual de procedimentos para os serviços de saúde. Brasilia: Ministério da Saúde; 2001.

22. Sociedade Brasileira de Patologia. Manual de Padronização de Laudos Histopatológicos. 4. ed. São Paulo: Manole Ltda; 2013.

23. Skincancer.org [Internet]. The Skin Cancer Foundation. Guide to Staging Melanoma. [cited 2017 Jan 19]. Available from: http://www.skincancer.org/ skin-cancer-information/melanoma/the-stages-of-melanoma/guide-to-stagingmelanoma.

24. Balch CM, Buzaid AC, Soong SJ, Atkins MB, Cascinelli N, Coit DG, et al. Final version of the American Joint Committee on Cancer staging system for cutaneous melanoma. J Clin Oncol. 2001;19:3635-48.

25. Leiter U, Garbe C. Epidemiology of melanoma and nonmelanoma skin cancer- the role of sunlight. Adv Exp Med Biol. 2008;624:89-103.

26. Oikarinen A, Raitio A. Melanoma and other skin cancer in circumpolar areas. Int $J$ Circumpolar Health. 2000 Jan;59:52-6.

27. Whiteman DC, Green AC, Olsen CM. Growing burden of invasive melanoma: projections of incidence rates and numbers of new cases in six susceptible populations through 2031. J Invest Dermatol. 2016:136:1161-71.

28. Apalla Z, Nashan D, Weller RB, Castellsagué X Skin Cancer: Epidemiology, Disease Burden, Pathophysiology, Diagnosis, and Therapeutic Approaches. Dermatol Ther (Heidelb). 2017;7(Suppl 1):S5-19.

29. Horsham C, Auster J, Sendall MC, Stoneham M, Youl P, Crane P, et al. Interventions to decrease skin cancer risk in outdoor workers: update to a 2007 systematic review. BMC Res Notes. 2014;7:10.

30. Xiang F, Lucas R, Hales S, Neale R. Incidence of Nonmelanoma Skin Cancer in Relation to Ambient UV Radiation in White Populations, 1978-2012 Empirical Relationships. JAMA Dermatol. 2014;150:1063-71.
31. Rubin Al, Chen EH, Ratner D. Basal Cell Carcinoma. N Engl J Med. 2005;353:2262-9.

32. Quintas RCS, Coutinho AL. Fatores de risco para o comprometimento de margens cirúrgicas nas ressecções de carcinomas basocelular. Rev. Bras. Cir. Plást.2008:23:116-9.

33. Silveira ML, Casalechi HL, Casalechi VL, Novo NF, Barbo MLP, Ruiz LRB Estudo epidemiológico dos carcinomas basocelulares, na população atendida no Conjunto Hospitalar de Sorocaba, no período de 2001 a 2005. Anais do X Encontro Latino Americano de Iniciação Científica e VII Encontro Latino Americano de Pós-Graduação; 2007 Out 18-19; São José dos Campos, Brasil. São José dos Campos: Universidade do Vale do Paraiba; 2007 . p. 1369-1372.

34. Ruppert L, Ofenloch R, Surber C, Diepgen T. Occupational risk factors for skin cancer and the availability of sun protection measures at German outdoor workplaces. Int Arch Occup Environ Health. 2016;89:1009-15.

35. Fischer AH, Wang TS, Yenokyan G, Kang S, Chien AL. Sunburn and sun-protective behaviors among adults with and without previous nonmelanoma skin cancer (NMSC): A population-based study. J Am Acad Dermatol. 2016;75:371-9.e5.

36. Hayashide JM, Minnicelli RS, Oliveira OAC, Sumita JM, Suzuki NM, Zambianco $\mathrm{CA}$, et al. Doenças de pele entre trabalhadores rurais expostos a radiação solar. Estudo integrado entre as áreas de Medicina do trabalho e Dermatologia. Rev Bras Med Trab.2010:8:97-104.

37. Chinem VP, Miot HA. Epidemiology of basal cell carcinoma. An Bras Dermatol. 2011:86:292-305

38. Inca.gov.br [Internt]. Instituto Nacional de Câncer José Alencar Gomes da Silva (INCA). Prevenção e fatores de risco. Exposição solar. Rio de Janeiro: Inca; 2016. [cited 2017 Jan 10]. Available from: http://www2.inca.gov.br/wps/wcm/connect/ cancer/site/prevencao-fatores-de-risco/exposicao solar.

39. Fartasch M, Diepgen TL, Schmitt J, Drexler $\mathrm{H}$. The relationship between occupational sun exposure and non-melanoma skin cancer: clinical basics, epidemiology, occupational disease evaluation, and prevention. Dtsch Arztebl Int. 2012;109:715-20.

40. Milon A, Bulliard JL, Vuilleumier L, Danuser B, Vernez D. Estimating the contribution of occupational solar ultraviolet exposure to skin cancer. $\mathrm{Br} J$ Dermatol. 2014;170:157-64.

\section{AUTHORS'CONTRIBUTIONS}

$\begin{array}{lll}\text { Natalia Miolo } & \text { (iD) ORCID 0000-0002-8370-3400 }\end{array}$

Statistical analysis; Approval of the final version of the manuscript; Conception and planning of the study; Elaboration and writing of the manuscript; Obtaining, analyzing and interpreting the data; Effective participation in research orientation; Intellectual participation in propaedeutic and/or therapeutic conduct of the cases studied; Critical review of the literature; Critical review of the manuscript

Rodrigo Fellipe Rodrigues (iD) ORCID 0000-0003-1465-6265

Conception and planning of the study; Elaboration and writing of manuscript; Obtaining, analyzing and interpreting the data; Critical review of the literature

Emanuelle Reis da Silva $\quad$ (iD) ORCID 0000-0001-7366-4324

Elaboration and writing of manuscript; Obtaining, analyzing and interpreting the data

$\begin{array}{lll}\text { Polyana Klomfass Piati } & \text { (iD) ORCID 0000-0003-0933-9521 }\end{array}$

Statistical analysis; Conception and planning of the study; Elaboration and writing of manuscript; Obtaining, analyzing and interpreting the data

Orley Alvaro Campagnolo (iD) ORCID 0000-0002-9769-2669

Approval of the final version of the manuscript; Conception and planning of the study; Effective participation in research orientation; Intellectual participation in the propaedeutic and/ or therapeutic conduct of the cases studied; Critical review of the literature; Critical review of the manuscript

Leandra Ferreira Marques (iD) ORCID 0000-0003-4790-2047

Approval of the final version of the manuscript; Elaboration and writing of manuscript; Effective participation in research orientation; Intellectual participation in the propaedeutic and/ or therapeutic conduct of the cases studied; Critical review of the literature; Critical review of the manuscript

How to cite this article: Miolo N, Rodrigues RF, Silva ER, Piati PK, Campagnolo OA, Marques LF. Skin cancer incidence in rural workers at a reference hospital in western Paraná. An Bras Dermatol. 2019;94(2):157-63. 